\title{
Dumping Ground or Country-in-Transition? Discourses of E-waste in South Africa
}

\author{
Mary Lawhon \\ African Centre for Cities \\ University of Cape Town \\ Rondebosch 7701 \\ marylawhon@gmail.com \\ +1.785 .383 .6251 or +27.79 .037 .6667$
}

\begin{abstract}
Electronic waste (e-waste) has become a point of interest for social and technical scientists, activists, and policy-makers. In South Africa, researchers, consultants and industry have worked together to develop plans for modernizing the e-waste industry while, at the same time, a group of activists connected to the global environmental justice movement is concerned with the illegal import of e-waste into South Africa. In this paper, I show how the discourses of ecological modernisation and environmental justice have been mobilized by these two different groups. The discourses have contrasting evaluations of the role of technology, relationship with the state, and the role of political economy which shape interactions between the discourses and discourse coalitions. Despite these differences, productive engagements exist. I suggest that understanding these differences can improve this engagement and contribute to more successful e-waste policy and management in the South African context and more widely.
\end{abstract}

Keywords: e-waste, South Africa, discourse, environmental justice, ecological modernisation 


\section{Introduction}

Like so many other "disposable" parts of our lives, most people give little or no thought to what happens after our various and diverse commodities turn into waste. Yet we are increasingly finding reasons to pay attention to waste for economic, environmental and social reasons. Electronic waste (e-waste) is one waste stream demanding our attention for all these reasons: businesses are finding economically profitable ways of recycling; environmentally, e-waste contains a small amount of hazardous materials; and most notoriously, e-waste "dumping" has evoked concerns over international environmental injustice. While there has been burgeoning research on environmental injustices, policy recommendations, management strategies and material aspects of e-waste, there has been limited interest in the discourses that shape these diverse responses. Discourses are based on assumptions, point to particular problem definitions and consequently enable particular solutions. Therefore, understanding discourses is important to understanding different strategies through which researchers and activists seek to understand and redress the challenges associated with e-waste.

In this paper, I examine environmental discourses underpinning different claims regarding the problems and solutions for e-waste in South Africa. Environmental justice (EJ) and ecological modernisation (EM) are two prominent discourses that underlie much environmental talk, and in many ways represent the two e-waste discourse coalitions internationally and in South Africa. Ecological modernisationists seek to apply lessons learned in Europe to the South African experience to establish allegedly "win-win" systems for improving the economic and environmental impacts of e-waste. While this work some the differences between contexts (e.g. lower wages in the global South) the efforts are based on a desire to modernize, regularize, and improve technological practices. In contrast, advocates of EJ seek to eliminate e-waste dumping in South Africa. However, both discourses are underpinned by (often implicit) assumptions regarding technology, the state and the global economy which, as I show below, do not apply to South Africa. Thus while these discourses provide useful shorthand framings, their utility is limited when translated out of their original contexts to South Africa and other similarly dynamic middle income countries.

In this paper, I first review the concept of discourse and key aspects of the discourses of EJ and EM. I then assess their relevance to the international e-waste literature, and show how these arguments have been adopted (largely without revision) in South Africa. Finally, I explore the relationship between the use of these two discourses, suggesting their limitations in South Africa as well as some potential points for revision, convergence and complementarity.

\section{Discourses of the environment}

The concept of discourse, and specifically, environmental discourse, has been widely used to examine how environmental change is talked about, how different framings emerge, and how they are used to develop and respond to particular power relations (Darier, 1999; Dryzek, 1997; Hajer, 1995; Watts, 2002). Discourses represent particular ways of constructing a problem, and as such enable or constrain associated solutions. Discourse coalitions entail common vocabulary, framings and associated solutions to particular problems that are developed through interactions and learning (Bulkeley, 2000; Hajer, 1995; 2003). Discourses emerge in context, and certain discourses become more prominent in particular places and times (Bulkeley, 2000; Hajer, 1995). While attention has been paid to how particular discourses change over time and space and some have shown the limitations of particular discourses, discourses may also be imported and used in ways which are inadequate to the context. Despite their emergence in particular contexts, international environmental 
discourses are seen to have much explanatory power in South Africa (Bond, 2000; Debbane and Keil, 2004; Oelofse et al., 2006). However, some recognition of the need to expand their scope, including Dixon and Ramutsidela (2006) who suggest the need to consider processes for achieving justice in the case of informal settlements and flooding. In this paper I focus on how these global discourses are used in the context of e-waste, their limitations, and how localizing the discourses can actually provide the scope for greater convergence and complementarity.

\section{Environmental justice}

The concept of environmetnal justice emerged in the 1980s to explain the inequitable distribution of environmental harm in the United States. Early EJ research primarily focused on quantitative documentation of patterns of spatial and political injustices, such as the concentration of waste facilities near communities of colour and exclusion from decisionmaking practices (Bullard, 1990, Holifield, 2001, Pulido, 2000). The concept has been applied to different dimensions of identity, including race, class and gender, and debates remain as to which is the dominant form of injustice (for a review, see Mohai et al., 2009). Further, various interpretations of justice have been used, ranging from Rawlsian distributive justice (meaning fair distribution of benefits and harms) to more expansive interpretations which include recognition and participation (Schlosberg, 2004). Some have sought to draw together conceptualizations into a more coherent framework (ibid), but there is also a growing awareness of the strategic benefits of the multiplicity of definitions, perspectives and uses of the term "as a discursive frame for activism, policy, and research" (Holifield et al 2009, p. 592).

While there have been some efforts to EJ concerns in existing sustainability frameworks (cf Pearsall, 2010, Pearsall and Pierce, 2010), others have sought to use social theory to understand why, despite decades of documentation and much action by civil society and governments, environmental injustices remain. Calls from the mid-1990s to "situate the production of inequalities with respect to broader social structures and political-economic processes" suggest a need to underlying reasons for injustice as well as the political obstacles for integrating justice concerns (Holifield 2009, p. 593). Researchers have subsequently drawn from, for example, political economy (cf Morello-Frosch 2002) and critical race theory (Pullido, 2000) and developed the more recent subfield of urban political ecology (Holifield et al., 2009).

The discourse of EJ has spread outside its original context to new places and scales (Walker, 2009). For example, in the UK, class is a more significant theme than racism and the discourse is more clearly associated with government than the grassroots. International EJ has increasingly become a subject of concern as disproportionate burdens of environmental hazards shift to the global South. Okereke (2006) discusses two of the most prominent cases of international injustices: the waste trade/dumping and climate change. His analysis suggests that, despite the inclusion of egalitarian principles of justice in international law, core policies remain rooted in neoliberalism. Climate justice has become one of the most prominent examples of international injustice, prompting responses by activists, researchers and governments (Lohman 2008). While many have argued for the need for justice at the global scale and in international agreements (Bond, 2008), Curran (2011) shows the difficulty of incorporating international justice concerns into national climate politics.

In South Africa, EJ has become a prominent component of the environmental movement since its introduction in the early 1990s (Cock and Koch, 1991, McDonald, 2002). There has 
been limited interest in quantitative documentation of injustice, but extensive research has documented the response of civil society to injustices, particularly in the South Durban region (Freund, 2001, Scott et al., 2002, Leonard and Pelling, 2010) and also more widely in South Africa (Steyn and Wessels, 2000, Hallowes, 2011). Most scholarship and activism focuses on injustice within South Africa, and South Africa has been less central to explorations of international EJ, although it plays a complex role in climate justice debates (South Africa's reliance on coal makes it a relatively large carbon emitter).

\section{Ecological modernisation}

Ecological modernisation has been observed to be the dominant discourse in environmental policy internationally (Buttel, 2000, Orsato and Clegg, 2005) and in South Africa specifically (Bond, 2000, Oelofse et al., 2006). Emerging in a similar time frame but with a contrasting emphasis to EJ, this perspective suggests that through human ingenuity and creativity, environmental and economic goals can be addressed simultaneously (Fisher and Freundenberg, 2001, Gibbs, 2008; Hajer, 1995). Technological innovation is the central key, and policies need to be reformed to enable the the intergration of environment and economy (Fisher and Freudenberg, 2001). Under such circumstances, development can be sustained through improvements in technology, design and policies which, for example, include environmental externalities. Additionally, EM has been noted to be a universalizing discourse, taking little account of particularities and context, although this is increasingly changing.

As with EJ, debate exists over the precise meaning of EM. Specifically, a key question exists as to whether it is an analytical lens through which to understand existing change, or a normative framework recommending change (Jepson et al., 2005). The latter perspective includes recommendations for how to better integrate environmental innovations into existing patterns of modernisation (Fisher and Freundenberg, 2001, Gibbs, 2008). Policy solutionsdeveloped through collaborations between the state and business establish win-win solutionsare widely seen as an essential avenue through which to achieve EM. Authors which use EM as an analytical lens point to changes in governance, including "decentralisation, marketbased mechanisms, participation of one-issue NGOs in monitoring and policymaking, and reliance on technology in environmental management" (Jepson et al., 2005, p. 297).

As with EJ, EM has responded to critiques and been adapted as it is considered outside its original context. In South Africa, it has limited resonance outside the academy and has generally been applied in its more classic "weak" form (as in Curran, 2011; cf Oelofse et al., 2006, Long and Patel, 2011). Others in contrast have shown the need for adaptation to industrializing economies and the global South (cf Jepson et al. 2005; Scheinberg and Mol, 2010). Critiques of EM suggest that the analysis and policy recommendations need to carefully examine and specify winners and losers, the empowered and disempowered, and problematize the universalized assumptions about appropriate practice (Orsato and Clegg, 2005). Additionally, while a collaborative state is generally assumed, this relationship needs more careful theorization (Buttel, 2000). In the African context, political will and capacity may well be lacking (Hagmann and Peclard, 2010; Young, 2004). Finally, its optimism of technology and the potential of innovation to redress environmental problems may well be overstated (Fisher and Freudenberg, 2001).

\section{Interactions between environmental justice and ecological modernisation}

In the literature reviewed above, EJ and EM are typically portrayed as opposing discourses (cf Bond, 2000; Long and Patel, 2010; Oelofse et al., 2006). Simply put, it has been 
suggested that EM focuses on the environment and economy, while EJ focuses on the social and environmental. Deep differences include skepticism vs optimism regarding technology, the relationship with the state, and contrasting interpretations of political economy. As Fisher and Freudenberg (2001, p. 703) note, "the relatively favorable interpretations of the role of technology in EM are sharply different from those in most established theories of environment - society relationships, which tend to view technological development and economic growth as being antithetical to environmental preservation" including EJ advocates. EJ advocates, particularly in South Africa, often place themselves outside and in opposition to the state (Scott and Barnett, 2009) while EM seeks close cooperative ties. In the EM discourse, a country's place in the global economic system is seen to be of limited consequence and all countries have the capacity to modernize, while the international EJ discourse focuses on the relationship between nations.

Despite these differences, as each discourse is revised as it extends outside its original context, there is increasingly scope for constructive engagement. Advocates for EJ, widely criticized in their early days for their NIMBY-ist arguments, no longer look solely at the distribution of impacts but instead seek overall reduction of environmental harm (Walker, 2009). EJ itself provides limited scope however through which to achieve this reduction in harm, but instead provides an impetus for broader environmental change including lobbying for increased regulation, better planning, and improved participation. Ecological modernisation, too, is changing. Orsato and Clegg (2005, p. 258) suggest the potential for creating a "critical EM" similar to the "strong EM" noted in Curran (2011) in which uncertainty and reflexivity replace technocentricism and neoliberalism. Research outside the OECD has also required an expanded theory. Rather than seeing EM as a uniform, comprehensive process, work in the global South has suggested the presence of modernized mixtures, or "sociotechnical configurations of infrastructures in which a variety of features of (modernising) systems have been deliberately and reflexively reconstructed in response to the challenge of a changing social, economic, and environmental context" (Scheinberg and Mol, 2010 p. 20).

Understanding these discourses not as inherently antithetical but as possibly containing points of convergence ${ }^{1}$ and complementary may thus create the potential for improved understanding of and responses to social, environmental and economic challenges (Buttel, 2000). More careful articulation of the role of technology, the state and political economy may enable more productive engagement between EM and EJ. Such complementarity is of course not inherent in either discourse. For example, the introduction of GMOs to Brazil, suggested to be an EM process, was highly contested by civil society advocates with justice concerns (Jepson et al. 2005). And while a strong EM may have much in common with EJ, translating such ideas into practice may well be both intellectually challenging and politically contested (Curran, 2011). However, assessing points of conflict, convergence and complementarity are necessary to understanding the potential for greater inclusion of both EM and EJ in policy and popular debate.

\section{E-waste: the scope of the problem}

Estimates of the worldwide generation of e-waste range from 20 to 50 million metric tons (UNEP 2006). While e-waste is only about $5 \%$ of consumer-generated waste (UNEP 2006) predictions from both the US and EU suggest that this is the fastest growing stream of waste (Puckett and Smith, 2002), and changes in technology such as the switch to LCD television

1 Importantly, this is not to say that all aspects converge, but my intention is to point to aspects which do. 
screens will only serve to exacerbate the rate of obsolescence and disposal. Further, the relative size underscores the danger of e-waste, which is classified as hazardous by the international community. In the global South, e-waste generation is expected to triple by 2010 (UNEP, 2006) and potentially even exceed that of the North by 2016-2018 (Yu et al., 2010).

Measuring e-waste volumes and their flows remains a difficult task. Conversion from use to waste is generally undocumented, flows are often covert, various definitions of e-waste exist and e-waste may be a sub-category of multiple kinds of waste (e.g. new and old monitors may be categorized the same, or e-waste may simply one component of the category "scrap metal: (Lepawsky and McNabb, 2010)). Measures of the sale of new electrical and electronic goods are easier to obtain, and proxies may be determined based on assumed rates of obsolescence (Muller et al., 2009). Lepawsky and McNabb (2010, p. 7) provide some indication of the global flows of e-waste (using the proxy of "waste and scrap of primary batteries, electric accumulators, spent primary batteries and spent electric accumulators") and suggest that despite their dominance in media narratives most e-waste flows are not NorthSouth.

\section{Methods}

In order to develop a narrative of the key e-waste discourses in South Africa, I first collected grey literature including meeting minutes, newsletters, and websites from various organizations. I then conducted interviews, field visits, and participatory observation at meetings and workshops from May-July 2009; Jan-Oct 2010; and Jan-April 2011 in Cape Town, Durban, Pietermaritzburg and Johannesburg. Twenty-five semi-structured interviews were held with key informants, beginning with those directly involved in the eWaste Association of South Africa (eWASA) and from there identified through a snow-balling method. Interviewees include: i) industry (manufacturers and recyclers); ii) NGOs (both employees of the NGO and informal recyclers participating in their recycling network); iii) government (at the provincial level, although not at national level); iv) employees of the eWaste Association of South Africa (eWASA) and v) consultants involved in the e-waste field. Subsequent to this, I have continued to attend meetings of the eWaste Alliance and the stakeholder consultation of the Information Technology Association of South AfricaProducer Environmental Group (ITA-PEG). eWASA has, as best could be determined, not held more recent meetings.

During the time of my fieldwork, many stakeholders were involved in the process of trying to change the e-waste system in South Africa. The particular dynamism of the moment meant that some respondents were reluctant to engage openly on the topic. Many large manufacturers refused interviews, explaining that they were in the process of developing their own internal positions in relation to wider debates. My only direct interactions with informal recyclers was at a landfill (facilitated by an NGO), complemented by interviews with members of a second NGO who worked with informal recyclers. These informants claimed that e-waste was a very minor part of their collection, and were not invested in an increase or decrease of this particular material, hence my limited efforts to engage them further. While many recyclers buy e-waste from informal collectors, the recyclers were generally not keen to facilitate an interviews with these informal suppliers. The recyclers suggested that the waste is typically collected directly from electronics repair shops, not the landfill, explaining the limited interest of my earlier respondents. Many interviewees were engaged repeatedly over the multiple phases of fieldwork. Interviewees have been named at their request, but the sensitive and contemporary nature of the research as well as my participation in meetings meant that many of my interactions were recorded in notes rather than in quotations. 


\section{E-waste: prevailing global discourses}

There has been a recent proliferation of policies, networks, and research on e-waste, most of which is underpinned by an interest in informing policy and/or practice (cf Lawhon et al., 2010). Much effort has been put into formalizing e-waste managements systems, exploring new technical approaches to reduce environmental harm, enhancing value from recycling, and stopping North-South e-waste exports, however, the assumptions underpinning each of these approaches typically remains implicit (ibid). To better understand the points of friction between the different technical and policy approaches, here I draw attention to how the particular versions of EJ and EM discourses are applied by e-waste researchers and practitioners.

\section{Environmental justice and e-waste}

The EJ implications of the dumping of e-waste are relatively straightforward: places with poor, non-white citizens bear the environmental burden of hazardous waste produced by mostly wealthy, white citizens (Pellow, 2007; Puckett and Smith, 2002). Lax environmental regulations and low labour costs create conditions under which nations in the global South (primarily in Southeast Asia and West Africa) are encouraged to accept e-waste from Northern nations. In some ways, this is merely a new iteration of the toxic colonialism identified in the 1980s which led to the Basel Convention on the Control of Transboundary Movements of Hazardous Wastes and their Disposal, which requires the consent of governments for the importation of hazardous waste. A later amendment to the convention prohibits the transboundary movement from countries in OECD to non-OECD countries, however, the amendment has not yet been ratified and brought into legal force. Additionally, transfers within these blocks remain legal and there are provisions under which specific trade agreements can be made to circumvent the ban (Lepawsky and McNabb, 2010).

This discourse emerged in the early 2000s after significant media attention to international ewaste dumping drew the attention of governments and scholars. While representations of ewaste in the global media have received limited analytical attention, articles with titles such as "The E-Waste Blight Grows More Dangerous Than Ever" (Kluger, 2011) and "Africa: Stop Dumping Hazardous Waste on Continent's Shores" (Walker, 2011) are typical in suggesting the hazards of e-waste and the ethical problems with its flows. Media stories frequently include evocative images of evidently poor women and children of colour amid piles of waste, smoky fires and flows of dirty water. A significant portion of the academic literature which followed the initial media interest also draws on and seeks to better theorize global flows in relation to EJ (Iles, 2004; Pellow, 2007). The media, activists and justice oriented scholars together sought to develop a framing largely oriented towards normative change.

Subsequent scholarship has challenged the simplified notions of North-South flows of ewaste flows portrayed in the media and early academic accounts (Lepawsky and Mather, in press). Additionally, the EJ literature has been criticized for discounting the economic potential of e-waste recycling (Widmer et al., 2005). Specifically, Schluep et al. (2009: 2) claim "the enormous resource impact of electrical and electronic equipment... is widely overlooked."

\section{Ecological modernisation and e-waste}

The explicit use of the discourse of EM is much less prominent in the e-waste literature and practice, although much of the research applies its underlying tenants. Park et al., (2010) for 
example, explicitly promote the adoption of EM in the Chinese e-waste industry as a means through which to improve economic and environmental practices. More generally, tools like life-cycle analysis, design-for-recycling, and cost-benefit analysis are proposed in e-waste research as objective, rational approaches in line with ecological modernisationist principles. These tools are intended to address technical and economic aspects of the problem (cf Kuehr and Williams, 2003).

Much effort has been put into developing strategies to internalize economic costs through subsidies to make e-waste recycling financially viable in the global North, again in line with EM (cf Dempsey and McIntyre, 2009). Specifically, extended producer responsibility as a strategy for cost internationalization has been closed linked to EM (Deutz, 2009). Pellow (2003) and Inagaki (2008) criticize the dominant EM responses to e-waste for their overemphasis on management systems, economic incentives, and technological advances and discounting the importance of justice. Importantly, the literature suggests weaknesses in the utility of both discourses, a point which I build on in my case study below.

\section{E-waste discourse in South Africa: in-transition or dumping ground?}

In this section, I analyse how discourses are used in the South African e-waste context. While Lawhon (2012a; 2012b) detail the specific actors, processes and power relations which inform the e-waste transition, the works inadequately explain the discourses that underpin the diverging opinions of different stakeholders. Given the importance of discourse in shaping power and practice, an analysis of particular assumptions and claims of the two competing discourse coalitions (EJ and EM) deepens our understandings of the process and power conflicts. While the discourses of EJ and EM implicitly or explicitly dominate the literature as well as policy prescriptions for e-waste internationally and in South Africa, I suggest that neither adequately explains the particularity of the case. I suggest below that there are benefits for refining and combining key insights from both by more clearly engaging with how understandings of technology, political economy, and power are enacted in South Africa.

\section{South African e-waste practice}

Much of the e-waste currently processed in South Africa reportedly comes from use within South Africa (Widmer and Lombard, 2005). Recycling is typically done by businesses who cherry-pick the most valuable components (ibid) but there is also a significant informal sector (Lymboussis, 2011). South Africa is, however, intimately connected to the international flow of electronics. First, most electrical and electronic goods are imported either through direct purchase, second-hand purchase and donation from the global North. Second, e-waste imports come from other parts of Africa. Companies such as HP import e-waste to South Africa from other African countries because of the higher processing standards, while other ewaste is imported to be recycled in South Africa because greater profits can be made here. Third, some e-waste materials collected in South Africa are sent to Asia, presumably to some of the facilities highly criticized for their inappropriate environmental precautions (Widmer and Lombard, 2005). Finally, some, Capetonian recyclers export PC boards- one of the most valuable components- to Europe for smelting (Schiller, e-waste recycler, personal communication, 2010).

Although as of early 2012, South Africa does not have an explicit policy on e-waste, according to M. Dittke (2007, p. 4) this "does not imply that South Africa has no legislation covering hazardous substances or waste, or the management and disposal thereof." Relevant legislation includes the 2008 National Environmental Management: Waste Act mandating the application of the waste hierarchy (avoid, reduce, reuse, recycle, then safely dispose of waste) 
as well as acts governing hazardous waste, pollution and precious metals (Dittke, 2007). South Africa is party to the Basel Convention, however it has not supported the Basel Ban Amendment, nor has it signed the Bamako Convention (Dittke, 2007). Dittke (2007: 38) argues this international legislation "has, in our opinion, only limited application for present purposes in South Africa since the majority of e-waste would probably be from local sources, as opposed to imported old or broken electronic/electrical equipment entering the country for recycling or treatment purposes." Regarding the Basel Convention, he argues that "It is, unfortunately, still a grey area whether e-waste strictly speaking must be regarded as hazardous waste for purposes of this Convention, although there is no reason why it should not be seen as such" (ibid: 38). While the 2008 Waste Act contains no mention of e-waste, the draft National Waste Management Strategy, developed to enable provisions of the Act, currently provides for the adoption of a national advanced recycling fee (ARF) although many in the electrical and electronic equipment manufacturing industry have publicly opposed this.

\section{The (weak) EM proponents}

Most of the grey and academic literature on e-waste in South Africa was developed out of a cooperative project with the Swiss Federal Laboratories for Materials Science and Technology (EMPA). The primary aim of the engagement was to raise awareness regarding the role of e-waste as a potential resource to keep in South Africa and a potential danger that needs to be more effectively managed. More recently, the ITA-PEG has also become a key player in e-waste management; importantly, while the details of their management proposal differ, it is largely underpinned by similar beliefs. As illustrated below, both eWASA and ITA-PEG support decentralized governance with an important role for industry in this, the need to integrate the environment and economy and the potential for win-win solutions, and the importance of technology and innovation in achieving better e-waste management.

The South African work emerging from this project has a technocratic ethos, suggesting that the primary problem is that South Africa lacks the appropriate systems to effectively manage e-waste. It uses evolutionary terminology to suggest South Africa simply needs Swiss technical assistance to "catch up with" the management systems in place in the North. For example, Widmer and Lombard (2005, p. 22) note that "a system similar to the Swiss SWICO system has not yet evolved. However, the metal recovery industry is becoming organised and may eventually recognise the need to organise a self-regulatory body with similar objectives to the SWICO system." Similarly, another paper from this project suggests an attempt to develop "a replicable concept for sustainable e-waste management and recycling in developing countries" (Schluep et al., 2008), suggestive of the universalizing tendency of weak EM. Further, in their work, the formal (modern) and informal (unmodern) sectors are contrasted, and the informal is clearly implicated in the negative practice. For example, Widmer et al. (2005) juxtapose two binaries: a (desirable) safe, formal (modern) system, or an (undesirable) unsafe (unmodern) informal system.

While the Swiss work is useful for providing a baseline of what is happening within the ewaste sector in South Africa, and social, economic and legislative context are provided explicit sections (cf Widmer and Lombard, 2005, p. 10-21), there is little sense of how the South African context impacts, constrains, and requires adjustments to the Swiss model. For example, Bondolfi (2007), a Swiss student, uses language throughout his publication normatively referring to "improper" actions and processes which e-waste "should" go through, normative and universalizing characteristics of EM. Additionally, and most fundamentally, this piece argues that his "model reveals many opportunities with advantages 
for all stakeholders" (Bondolfi 2007, p. 4). Benefits are noted as reasons to encourage participation in the system, suggesting the possibility for win-win solutions that benefit the environment and economy. There is no analysis of the serious differences in terms of power relations and ethical questions regarding who specifically should be paying these costs.

Following the Swiss model and clearly a local manifestation of the Swiss discourse, the eWaste Association of South Africa (eWASA) was established as an industry-led body with members including manufacturers, recyclers, and refurbishers (Anderson, eWASA chairman, personal communication, 2010; Ecrinogard, eWASA office manager, personal communication, 2010). This model clearly follows the principles of EM in which businesses can be established for the benefit of both the economy and environment. Further, eWASA seeks to work with government to help establish a regulatory framework (ibid). As Jepson et al. (2005) argue, support for such collaborative relations and decentralized governance is also characteristic of the environmental modernisation discourse.

In the process of establishing a new e-waste management system, disagreements arose between eWASA and various manufacturers on the particular type of management strategy proposed (the original eWASA proposal was based on the Swiss ARF). Specifically, Ruben Janse van Rensburg, Environmental Manager for English Africa of Hewlett-Packard, after consultation with his European supervisors, began promoting the introduction of an alternative e-waste management system (personal communication, 2010). This has been developed into a new forum of manufacturers, now called the ITA-PEG (see Lawhon 2012b), and both eWASA and the ITA-PEG have Industry Waste Management Plans, released for comment subsequent to my interviews. While to date debate remains over which system will develop the best answer (and stakeholders are actively lobbying for what appears best for them) and/or which will be applied in South Africa, the important issue in this paper is the remarkable overlap in terms of the questions being asked by the two groups which clearly position both organizations within the field of EM.

The first point of consideration repeated by both Anderson, of eWASA (personal communication 2010; 2011) and Ruben Janse van Rensburg of HP and instrumental in the formation of ITA-PEG (personal communication, 2010; 2011; 2012) is the efficiency of the system. Anderson repeatedly insisted that a single, unified system enabled efficiency, and the management plan notes the benefits of "economies of scale (eWASA, 2011, p. 4). Further, "a commercial tender process will be instituted in order to allow for free competition in the allocation of e-waste transport and storage contracts." In contrast, van Rensburg insisted that competition was the key to efficiency and that eWASA was inadequately competitive. The ITA-PEG draft claims that having multiple collection schemes will result in the "ability to efficiently organise the collection and treatment of e-waste." Considerations of efficiency included cost, and van Rensburg referenced and subsequently emailed me a copy of cost comparisons of competitive vs consolidated e-waste management systems to support his case. While Anderson suggested that innovation would occur amongst recyclers in order to gain tenders from the centralised system, van Rensburg emphasized that more innovation would happen in a decentralized system in which different manufacturers would look for different kinds of innovation. Van Rensburg also claimed that product redesign is best incentivized in a competitive system, although also aware that what happens in South Africa may be on too small of a scale to impact the design of goods produced elsewhere.

These questions raised by eWASA and ITA-PEG clearly fall within the parameters of the ecological modernist discourse, and are clearly linked to the interests of the multinational 
manufacturers which dominate both eWASA and the SA WEEE Producers' Forum. Importantly, the focus of conversations is not on which group should have the legitimacy to determine an e-waste management system or who will benefit from such a system, (as raised in Lawhon, 2012) but on the idealized models of the systems themselves. Although at has been repeatedly implied that eWASA's chairman will profit out of the eWASA system, the broader questions of justice are outside the discourse, sidelined by the boundaries of the EM framing.

\subsection{The EJ advocates}

While these efforts are being made to improve practices among formal recyclers, an environmental and social justice NGO has developed an alternative focus through an alternative network. groundWork has worked with the Basel Action Network to oppose the export of hazardous waste into Africa, and e-waste forms part of this campaign. While groundWork is a member of eWASA and Euripedou of groundWork has attended eWASA meetings, Euripedou (personal communication, 2010) clearly stated that the NGO's priority is stopping North-South flows. groundWork and BAN have received much less attention from government and the media in South Africa around their concerns than organizations such as eWASA, in part because e-waste is but one small aspect of their larger portfolio.

While initially quite interested in the idea of an e-waste association, Euripedou reported that he rather quickly became frustrated with its apolitical approach (personal communication, 2010). In May 2009, BAN informed South African authorities that e-waste collected in the US was on its way to South Africa for recycling ${ }^{2}$. groundWork shared this information with eWASA, the South African Revenue Service and the national Department of Environmental Affairs and Tourism (Euripidou, personal communication 2010). Despite this knowledge, the South African government proved unable to stop the shipment and it entered Durban harbour later that month. The shipment has since travelled inland to Johannesburg where, as best can be determined, it still remains under government oversight and cannot be returned because of legal ambiguities regarding ownership of the e-waste (ibid.). The precise legalities, however, matter less to groundWork than the principles, as a statement on another hazardous waste import suggests: "The fact [the Basel Ban] amendment remains in the course of garnering the necessary ratifications to enter into official legal force, in no way detracts from the fact that the Parties to the Basel Convention, Lome Convention, and the Organization of African Unity are on record as clearly having condemned such toxic trade imports to Africa (Ambler 2000, n.p.).

groundWork reported this case in its newsletter as well as in a publication through Global Information Society Watch (Lawhon and Euripedou, 2010). However, as my co-authorship on this report suggests ${ }^{3}$, the NGO has limited capacity and even the import of e-waste is not high on its priority list. groundWork works extensively with informal waste recyclers, but the domestic e-waste situation plays a much less significant role for the NGO. Further, it was suggested that shipment was likely intended for the formal sector (anonymous recycler, personal communication, 2010). In the South African case, therefore, the anti-import EJ NGO is also the most active NGO in organizing and building support for informal waste recyclers.

2 Personal communication with anonymous recyclers suggests that e-waste imports are not uncommon, often under the guise of second hand electronics.

3 We clearly distinguished our respective roles; I re-wrote text based on my interview with Euripedou, other research and the groundWork newsletter while Euripedou was responsible for the recommendations and final editing. 
In this context, eWASA subsequently used its connections with government to raise this concern, and formally made the following statement opposing the importation included in the groundWork newsletter: "eWASA strongly opposes illegal transboundary movement of ewaste into the country, while shipments of waste destined for recycling facilities where it can be handled safely, especially from other African countries who lack treatment facilities, should be considered on a case by case basis by the authorities" (eWASA, quoted in Euripedou, 2009, p. 7). These assertions were made despite this legal ambiguity (and the potential for bi- or multi-lateral agreements under the Basel Convention) of e-waste imports (M. Dittke, 2007). In interviews, both the Western Cape coordinator (S. Dittke, personal communication, 2010) and office manager (Ecrinogard, personal communication, 2010) asserted that e-waste imports from the global North were not legal and became very animated in their response to the question. Further, both argued that a policy explicitly allowing ewaste imports would be politically unpalatable, and this position is highly unlikely to change given the anti-import position of key individuals within the responsible branches of the national Department of Environmental Affairs.

Despite this interest from eWASA, although government has reportedly not acted in response to the allegedly illegal import (in my interviews with two government officials, both reported they knew nothing of the case, even though documentation suggests they were informed), eWASA took no further action. Euripidou of groundWork was frustrated at this limited action, (personal communication, 2010), arguing that an e-waste association should include ensuring adherence to international principles in its remit. This example further supports the argument that eWASA positions itself is a cooperative partner for government, not in opposition.

\section{Limitations of EM and EJ}

Many of these limitations of both discourses can be traced back to the differences between EM and EJ regarding the role of technology, association with the state, and global political economy, and the inapplicability of typical discourses to the South African case. The use of the EM discourse has helped mobilize resources to improve e-waste management in South Africa. However, the current failings to instigate real change suggest the limitations of the EM discourse. First, the state has unable or unwilling to defer the authority to govern to the new associations, nor actively supported them, suggesting that the version of the state and governance in South Africa differs from that assumed by EM. Second, the discourse portrays the proposed new e-waste system as inherently beneficial to all members with clear distinctions between good and bad practice. However, as Lawhon (2012a; 2012b) illustrates, there will be winners and losers in any e-waste transition and this has resulted in contestation over power. Further, while the proposed models have attempted to include informal e-waste recyclers, when interviewed, neither eWASA nor ITA-PEG had consulted in depth with these stakeholders nor provided scope for their inclusion, let alone empowerment ${ }^{4}$. As suggested in early works by the Swiss, the informal is associated with improper environmental management, and therefore has no place in the new system. Importantly, some stakeholders within eWASA have begun asking reflexive questions in line with strong EM. Environmental NGOs as well as the eWaste Alliance (a group of recyclers in Cape Town) have asked which of the proposed models will enable the success of existing small recyclers and how the

4 There is the potential for informal collectors to sell materials into the system, but simultaneously there are initiatives to move materials directly from consumers into the ewaste stream, eliminating this role. Thus, the informal sector may well be sidelined in the process. 
informal sector will be included (Dittke, personal communication, 2010; Schiller, personal communication, 2010).

Viewing the South African case solely through the lens of EJ has similarly proven to be a short-sighted solution for both ethical and pragmatic reasons. When asked his/her views about e-waste imports, one anonymous recycler (personal communication, 2010) claimed that he/she regularly imported "waste" as "second hand electronics". He/she claimed to follow adequate precautions, and argued that the consequent job creation made it worth the minor environmental risks. Further, should e-waste management standards improve, then the rationale for the ban on imports may no longer hold. As Okereke (2006: 730) argues, "global waste management policies must be designed against the backdrop that developing countries have limited capabilities to manage wastes" but if this is no longer the case, new principles need to be articulated. This position was supported by an anonymous government employee (2010) who claimed that, provided appropriate standards are in place, South Africa is a good place for e-waste recycling. Further, in the case of South African e-waste, it may well be that low labour costs, not the low environmental standards, attract the imports. The definition and type of justice thus becomes important, as economic imperatives may be of greater significance.

There are also pragmatic concerns with using a ban to address the broader problem of e-waste processing in the global South. As the Durban import which remains in storage shows, legally establishing and enforcing a ban on imports has proven incredibly difficult. Given that the economic inequalities which drive the system are unlikely to change, e-waste imports are unlikely to end without significant resistance. In addition to this, a growing amount of ewaste is being generated in the global South (Widmer et al., 2005; Yu et al., 2010). While per capita quantities remain low, the growth rate is highest in the South. For example, PC growth from 1993-2000 was nearly 3,000\% in Zimbabwe and over 2,000\% in China (Widmer et al., 2005). Thus even if imports of e-waste cease, there is a growing need for the management of e-waste produced and consumed in the global South. While alleviating the overt international justice concerns, a successful ban on e-waste imports would not solve the problem of e-waste disposal in the global South.

\section{Points of convergence and complementarity}

Many of the points of convergence and complementarity between the discourses are rooted in reflexive, contextual understandings of the role of technology, association with the state, and global political economy based on the South African case. Ecological modernisationists clearly believed technology has the potential to limit environmental harm, and groundWork agrees that technology can play a role in improving practice (Euripedou, personal communication, 2010). EJ advocates understand the potential for electronics to bridge the digital divide and contribute to social development, and even groundWork is not opposed to second-hand imports in principle (Euripidou, personal communication, 2010). There is, therefore, a level of complementarity to these positions.

Importantly, despite some participation in eWASA, EJ advocates have generally not been engaged in critical debates as to what kind of e-waste management system is most appropriate in South Africa. However, while international EJ is a noted concern for groundWork, a greater environmental, human health, and social justice problem may well be resulting from waste consumed within or legally imported from neighboring countries. groundWork needs to be able to work with other organizations who This is understandable given the significance of other issues and the level of detailed information required to 
understand who may benefit from what system. This not intended as a critique, but instead to illustrate the problem of limiting justice concerns to EJ NGOs. While there has been no consultation, the informal sector has been included in more recent schematics of the eWASA system. This suggests an interest in inclusion, and the possibility that groundWork could be consulted on a more specific basis rather than throughout the entire process of establishing a new system. groundWork's experience in working with the informal sector complements the interests but limited knowledge of organizations such as eWASA and ITA-PEG. The combined insights may provide the scope for a modernised mixture along the lines of Scheinberg and Mol (2010) which includes the informal sector and improves environmental outcomes.

eWASA and ITA-PEG have clearly positioned themselves in collaboration with the state, and groundWork typically positions itself in opposition. Yet as Scott and Barnett (2009) illustrate, South African EJ advocates often employ both oppositional and collaborate strategies. Such a constructive dualism may well be appropriate for groups like eWASA, enabling them to take on an advocacy role in relation to international trade as well as enforcement of domestic regulations. Finally, both EMists and EJ advocates clearly need more careful understanding of South Africa's complex role in the global e-waste economy and of the potential for more beneficial engagement. South Africa is clearly not a major international dumping ground for e-waste. Simultaneously, limited technology, relatively low densities of e-waste and distance from places of high e-waste density mean that it simply cannot model its practices on those of Europe without much more significant financial support.

\section{Conclusion}

This overview of the prevailing discourses on e-waste in South Africa highlights the limitations of the current ways in which e-waste is being conceptualized in middle income countries such as South Africa. Importantly the limited scope for conversations about justice in the two key organizations most likely to govern e-waste in future has resulted in a splintering of efforts. While efforts have been made to engage eWASA on justice issues by various NGOs, the failings thus far suggest the need to find new more explicit ways of including social issues into the mainstream e-waste debate. Simultaneously, EJ NGOs have been unable to mobilize support against e-waste imports such that imports are clearly illegal, and when caught, sent out of the country.

There is the potential for an organization such as eWASA to include elements of both strong EM and EJ. Should it seek this role, there is a need to reconsider how justice can be included into its core vision, management plans, and practice. Given that e-waste will continue to be an increasingly significant part of the domestic waste stream in the South particularly in middle income countries, and the challenges of enforcing existing legislation which bans dumping, there is a need for new ways to analyse e-waste in countries like South Africa which fall between the prevailing discourses. If our main goal is to eliminate environmental injustice, then better enforcement of the Basel Ban may be an appropriate way forward. But if the deeper concern is protecting human and environmental health from hazards processing of e-waste, there may be a need to rethink the focus of campaigns. Justice and the environment need not be contradictory, but nor are they necessarily mutually reinforcing. Due attention is required to structural limitations, and the points for convergence need be clearly identified. In this context, we can work to intentionally cultivate strategies which enable practices which accord with aspects of both EM and EJ. 


\section{References}

Agrawal A, 2005, Environmentality: Technologies of Government and the Making of

Subjects. (Duke University Press, Durham, NC)

Blaikie P, 1985, The Political Economy of Soil Erosion in Developing Countries (Longman, London)

Bond P, 2000, "Economic growth, ecological modernisation or environmental justice? conflicting discourses in post-apartheid South Africa" Capitalism, Nature, Socialism 11(1) $33-61$

Bond P, 2008, "The state of the global Carbon Trade Debate" Capitalism Nature Socialism 18(4), 89-106

Bondolfi A, Schluep M, Ecroignard L, and Finlay A, 2007, The "Green e-Waste Channel" as an environmentally friendly and socially responsible concept to manage e-waste in emerging economies. World Congress, Recovery of Materials and Energy for Resource Efficiency Conference Proceedings. (http://ewasteguide.info/biblio/the-\%E2\%80\%9Cgreen-e-)

Accessed 10 Nov 2011

Bullard R, 1990, Dumping in Dixie: Race, Class, and Environmental Quality (Westview Press, Boulder, CO)

Bulkeley H, 2000, "Discourse coalitions and the Australian climate change policy network" Environment and Planning C 18(6) 727- 748

Buttel F, 2000, "Ecological modernisation as social theory" Geoforum 31 57-65

Cock J, Koch E, eds, 1991, Going Green: People, Politics and the Environment in South Africa. (Oxford University Press, Cape Town)

Cohen M J, 2006, "Ecological modernisation and its discontents: The American environmental movement's resistance to an innovation-driven future" Futures, 38, 528-547.

Curran G, 2011, "Modernising climate policy in Australia: climate narratives and the undoing of a Prime Minister" Environment and Planning C, 29(6), 1004-1017

Debbané A, Keil R, 2004, Multiple disconnections: environmental justice and urban water in Canada and South Africa Space and Polity 8(2) 209-225

Dempsey M, McInryre C, 2009, The role of collective versus individual producer responsibility in e-waste management: key learnings from around the world in Hester RE and Harrison RM eds Electronic Waste Management. (Cambridge University Press, Cambridge, UK) pp 212-235

Deutz P, Frostick L, 2009, Reconciling policy, practice and theorisation of waste management The Geographical Journal 175(4) 274-285

Dixon J, Ramutsindela M, 2006, Urban resettlement and environmental justice in Cape Town Cities 23(2) 129-139 
Dittke M, 2007, A Review of South African Environmental and General Legislation Governing ewaste, eWASA, Johannesburg

EPA, 2011, Electronics Waste Management in the United States Through 2009 May (http://www.epa.gov/wastes/conserve/materials/ecycling/docs/fullbaselinereport2011.pdf) Accessed 21 July 2012

Euripidou, R, 2009 "U.S. e-Waste lands in South Africa" groundWork Newsletter 11(3) 4-8 www.groundwork.org.za/Newsletters/Sept\%202009\%20WEB.pdf

eWASA, 2011, Industry Waste

Management Plan Draft v3.4

(http://www.ewasa.org/downloads/files/iwmp/ewasa_iwmp_draft_v3.4.pdf) Accessed 21 July 2012

Feindt P H, Oels A, 2005, "Does discourse matter? Discourse analysis in environmental policy making” Journal of Environmental Policy and Planning, 7(3), 1-13.

Finlay A, Liechti D, 2008, e-Waste assessment South Africa. Technical report, e-Waste Association of South Africa (http://ewasteguide.info/Finlay_2008_eWASA) Accessed 30 May 2010.

Fisher D R, Freudenburg W R, 2001, "Ecological modernisation and its critics: Assessing the past and looking toward the future" Society \& Natural Resources 14 701-709

Freund B, 2001, Brown and green in Durban: the evolution of environmental policy in a postapartheid city. International Journal of Urban and Regional Research 25(4) 717-739.

Gibbs D, 2006, "Prospects for an environmental economic geography: Linking ecological modernisation and regulationist approaches" Economic Geography 82(2) 193-215

Government Accounting Office (GAO), 2008, Electronic Waste: EPA Needs to Better Control Harmful U.S. Exports through Stronger Enforcement and More Comprehensive Regulation. (www.gao.gov/new.items/d081044.pdf) Accessed 30 May 2010

Hagmann T and Péclard D, 2010, "Negotiating statehood: dynamics of power and domination in Africa" Development and Change 41 539-562

Hajer M, 1995, The politics of environmental discourse: Ecological modernisation and the policy process (Clarendon Press, Oxford)

Hallowes D, 2011, Toxic Futures: South Africa in the Crises of Energy, Environment and Capital (University of KwaZulu-Natal Press, Pietermaritzburg)

Holifield R, 2001, "Defining environmental justice and environmental racism" Urban Geography 22(1) 78-90 
Holifield R, Porter M, and Walker G, 2009, "Spaces of environmental justice: frameworks for critical engagement" Antipode 41(4), 591-612

Iles A, 2004, "Mapping environmental justice in technology flows: computer waste impacts in Asia" Global Environmental Politics 4(4) 76-107

Inagaki H, 2008, The Myth of 'Environmentally Sound' Management of E-waste: A case study from computer recycling activities in Delhi, India. Unpublished Masters Thesis, Institute of Social Studies, The Hague, The Netherlands

Jepson WE, Brannstrom C, and de Souza RS 2005, “A case of contested ecological modernisation: the governance of genetically modified crops in Brazil" Environment and Planning C 23(2), 295-310

Kahhat R, Kim J, Xu M, Allenby B, Williams E, Zhang P, 2008, "Exploring e-waste management systems in the United States" Resources, Conservation and Recycling 52(7) 955-964

Keil R, Debbané, A M, 2005, "Scaling discourse analysis: experiences from Hermanus , South Africa and Walvis Bay, Namibia" Journal of Environmental Policy \& Planning 7(3): 257-276

Kluger J, 2011, E-Waste blight grows more dangerous than ever Time (http://ecocentric.blogs.time.com/2011/11/01/the-e-waste-blight-grows-more-dangerous-thanever/) Accessed 10 Nov 2011

Kuehr R, Williams E, 2003, Computers and the Environment: Understanding and Managing their Impacts (Kluwer Academic Publishers, The Netherlands)

Lawhon M, Manomaivibool P, Inagaki H, 2010, "Solving/Understanding/Evaluating the EWaste Challenge through Transdisciplinarity?” Futures 42 1212-1221

Lawhon M, 2012a, "Power, Trust and Legitimacy in the Governance of the South African EWaste Transition." Environment and Planning A.

Lawhon M, 2012b, "Contesting power, trust and legitimacy in the South African e-waste transition" Policy Sciences.

Leonard L, Pelling M, 2010, "Mobilisation and protest: environmental justice in Durban, South Africa." Local Environment, 15(2), 137-151

Lepawsky J, Mather C, In Press, "From Beginnings and Endings to Boundaries and Edges: rethinking circulation and exchange through electronic waste" Area

Lepawsky J, McNabb C, 2010, "Mapping the international trade and traffic of electronic waste" The Canadian Geographer 54(2)1 77-195

Lohmann L, 2008, Carbon trading, climate justice and the production of ignorance: ten examples" 359-365 
Long DP, Patel Z, 2010, "A new theory for an age-old problem : ecological modernisation and the production of nuclear energy in South Africa" South African Geographical Journal 93(2) 191-205

Lymboussis J, 2011, Approaching the informal sector as part of the solution: An Understanding of Current Informal E-Waste Processes in South Africa, with a Focus on KwaZulu-Natal Province Unpublished dissertation. Imperial College London

Mander S, 2008, "The role of discourse coalitions in planning for renewable energy: a case study of wind-energy deployment" Environment and Planning C: Government and Policy 26(3) $583-600$

Martinez-Alier J, 2003, "Problems of ecological degradation: environmental justice or ecological modernisation?" Capitalism, Nature, Socialism $14133-$

Mohai P, Pellow D, Roberts JT, 2009, "Environmental justice" Annual Review of Environment and Resources, 34(1), 405-430

Morello-Frosch R, 2002, "Discrimination and the political economy of environmental inequality" Environment and Planning C 20(4), 477-496

Müller E, Schluep M, Widmer R, Gottschalk F, and Böni H, 2009, Assessment of e-waste flows: a probabilistic approach to quantify e-waste based on world ICT and development indicators

(http://ewasteguide.info/files/Mueller_2009_R09.pdf) Accessed 21 July 2012

Oelofse C, Scott D, Oelofse G, Houghton J, 2006, "Shifts within ecological modernisation in South Africa: Deliberation, innovation and institutional opportunities" Local Environment 11(1) $61-78$

Okereke C, 2006, "Global environmental sustainability: intragenerational equity and conceptions of justice in multilateral environmental regimes" Geoforum 37 725-738

Orsato RJ, Clegg SR, 2005, "Radical reformism: towards critical ecological modernisation" Sustainable Development 13(4) 253-267

Park J, Sarkis J, Wu Z, 2010, “Creating integrated business and environmental value within the context of China's circular economy and ecological modernisation" Journal of Cleaner Production 18(8) 1494-1501

Patel Z, 2009, "Environmental justice in South Africa: tools and tradeoffs" Social Dynamics 35(1) 94-110

Pearsall H, 2010, "From brown to green? Assessing social vulnerability to environmental gentrification in New York City" Environment and Planning C 28(5), 872-886

Pearsall H and Pierce J, 2010, "Urban sustainability and environmental justice: evaluating the linkages in public planning/policy discourse" Local Environment 15(6), 569-580 
Pellow DN, 2007, Resisting Global Toxics: Transnational Movements for Environmental Justice (MIT Press, Boston)

Puckett J, Smith T, 2002, Exporting Harm: The High-Tech Trashing of Asia (The Basel Action Network, Silicon Valley Toxics Coalition, Seattle)

Pulido L, 2000, "Rethinking environmental racism: white privilege and urban development in southern California" Annals of the Association of American Geographers 90(1) 12-40

Scheinberg A, and Mol APJ, 2010, "Multiple modernities: transitional Bulgaria and the ecological modernisation of solid waste management" Environment and Planning C 28(1), $18-36$

Schluep M, Hagelüken C, Meskers C E M, Magalini F, Wang F, Müller E, Kuehr R, Maurer C, Sonnemann G, 2009 "Market potential of innovative e-waste recycling technologies in developing countries" (http://ewasteguide.info/files/Schluep_2009_R09.pdf) Accessed 13 March 2012

Schluep M, Dittke S, Newson G, Kane C and Hieronymi K 2008 “A material recovery facility in Cape Town, South Africa, as a replicable concept for sustainable e-waste management and recycling in developing countries." Global Symposium on Recycling, Waste Treatment and Clean Technology (http://ewasteguide.info/2008_Schluep_REWAS) Accessed 10 Nov 2011

Schlosberg D, 2004, "Reconceiving environmental justice: global movements and political theories" Environmental Politics 13(3) 517-540

Scott D, Oelofse, C, Guy C, 2002, "Double trouble : environmental injustice in South Durban" Agenda, 52 50-57

Scott D, Barnett C, 2009, "Something in the air: civic science and contentious environmental politics in post-apartheid South Africa" Geoforum, 40(3) 373-382

Stevenson R, 2009, "Discourse, power, and energy conflicts: understanding Welsh renewable energy planning policy" Environment and Planning C: Government and Policy 27(3) 512 526

Steyn P, Wessels A, 2000, "The emergence of new environmentalism in South Africa, 19881992” South African Historical Journal 42(1), 210-231

United Nations Environment Programme (UNEP) 2006 Basel Conference Addresses

Electronic Wastes Challenge

(http://www.unep.org/Documents.Multilingual/Default.asp?DocumentID=485\&ArticleID=54 $31 \& \mathrm{l}=\mathrm{en})$ Accessed 5 Nov 2009

Walker G, 2009, “Globalizing environmental justice: the geography and politics of frame contextualization and evolution" Global Social Policy 9(3) 355-382

Walker T, 2011, Africa: Stop dumping waste on continent's shores. All Africa (http://allafrica.com/stories/201111030003.html) Accessed 10 Nov 2011 
Wang F, 2008, Economic conditions for developing large scale WEEE recycling infrastructure based on manual dismantling in China- The learning experience from the setup of a pilot plant. Masters dissertation. Delft University of Technology.

Watts M J, 2002, “Green capitalism, green governmentality” American Behavioral Scientist 45(9) 1313-1317

Widmer R, Oswald-Krapf H, Sinha-Khetriwal D, Schnellmann M, Boni H, 2005, "Global perspectives on e-waste" Environmental Impact Assessment Review 25 436-458

Widmer R, Lombard R, 2005, "e-Waste Assessment in South Africa: A case study of the Gauteng Province" Swiss Knowledge Partnerships in e-Waste Recycling, Swiss Federal Laboratories for Materials Testing and Research. St. Gallen, Switzerland

Young C, 2004 "The End of the Postcolonial State in Africa? Reflections on Changing African Political Dynamics" African Affairs 103 23-49

Yu J, Williams E, Ju M, Yang Y, 2010, "Forecasting global generation of obsolete personal computers" Environmental Science Technology 44(9) 3232-3237 